\title{
LOUVRE ABU-DHABI OR THE MYTH OF WESTERNALISM
}

\section{Litova}

Daria S. Litova - MGIMO University alumna (International Relations - Area Studies), MSc student in Cultural Narratives and Comparative Literature (triple degree of the University of St Andrews, Universidade NOVA Lisboa\&Université de Perpignan). 1069-061, Lisboa, Avenida Berna, 26 C. E-mail: darya.litova@gmail.com

Litova D. Louvre Abu-Dhabi or the Myth of Westernalism. Concept: Philosophy, Religion, Culture.

Vol. 4. № 1(13). P. 194-200. https://doi.org/0.24833/2541-8831-2020-1-13-194-200

Received: 07.11.2019 Accepted: 02.02.2020.

Conflicts of interest. The author declares absence of conflicts of interest.

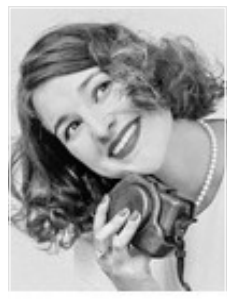

Abstract. The study of the phenomenon of the Louvre Abu Dhabi (the Middle East Louvre Museum) from the historical and cultural points of view is relevant in several aspects.

Firstly, the very fact of the creation of this museum is of interest. It operates as a kind of «successor» and «interpreter» of the Western tradition, which determines its Kulturträger activity. The history of the acquisition of the Mesopotamian collection by the Louvre Abu Dhabi serves as a case study.

Secondly, based on this material it is possible to trace the main characteristics of modern identity-building strategies and the build-up of "soft power». Moreover, it allows to reveal how alternative cultural-centric versions of social development are elaborated. This alternative reconsiders the thesis of the dominance of the "center» not in favor of the West. The analysis of the original way of presenting the «Western» cultural content within the framework of the «nonwestern» cultural code allows us to raise the question of the probable relapse at a symbolic level of cultural imperialism. It has its reflections in the specifics of the organization of the museum space and the features of the exposition of the Louvre Abu Dhabi. The analysis allows to predict more clearly the possible cultural consequences of the museum's creation. Thirdly, an attempt to model the museum's cultural practices through appeal to the concepts of «mythology» and «myth» developed by Roland Barthes is of a theoretical value. The modeling comprises culturological interpretation of the museum's activities through the prism of Roland Barthes' Mythologies. It allows us to raise the questions regarding the possibilities and boundaries. E.g., whether traditional cultural symbols could be used as elements of «soft power». Furthermore, it becomes possible to describe the limited nature of «soft power» as a means of symbolic authority.

Keywords: post-colonialism, postmodernism, cultural citations, Barthes, soft power, Louvre, museum studies, architecture, light, mythologies. 
$\mathrm{I}$ n the year 2017, the city of Abu-Dhabi opened the Middle-Eastern Louvre Museum, or, to use a more common name, Louvre Abu-Dhabi. The estimated costs of this fascinating cultural oasis come up to $\$ 1$ billion. Emirates are renting the name «Louvre». Five hundred million euros were paid for the name's use for 30 years. There is no certainty about what happens after this term.

Taking in mind the pleiad of United Arab Emirates' most recent ambitious international projects, such as the World archipelago, Mall of the World, Dubai Frame and Burj Khalifa, we could agree with the position that Abu Dhabi's mission to promote a message of acceptance, and openness (Business Wire) (see Figures 1,2).

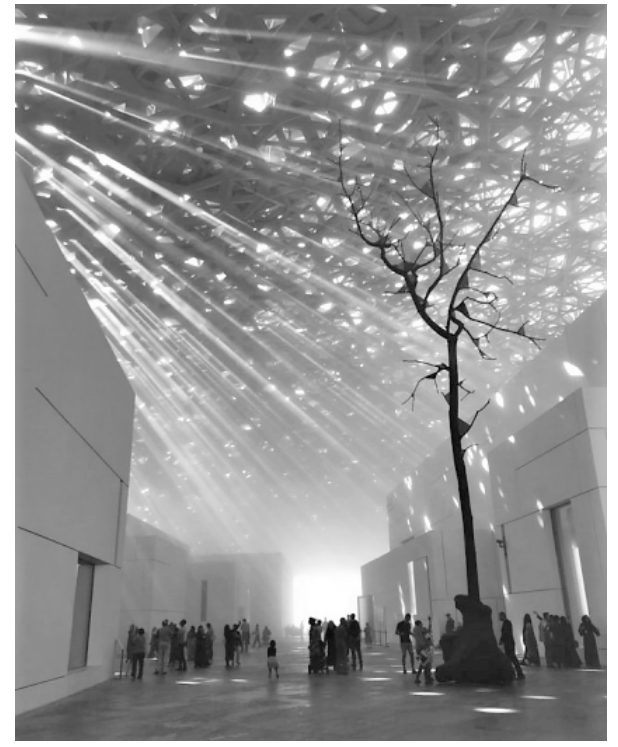

Figure 1. (C) Instagram @dohaabushal

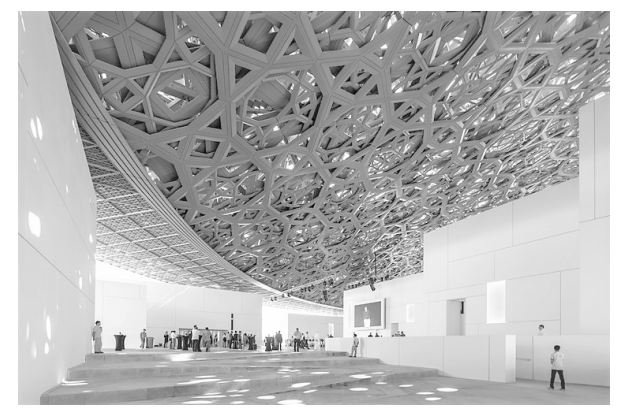

Figure 2. Laurian Ghinitoiu
In the area, which also comprises a campus of a new university and 30 hotels, the magnificent building with a turtle-like 590 feet in diameter dome hinting at creator's megalomania symbolically extends in the Gulf. The dome has no ceiling and no walls, being not a building in a literal sense, but an Arabian agora [as the principal architect, Jean Nouvel described it] with birds and insects flying about and the wind coming through.

Entering the museum, the visitors become fascinated with the light 'raining' from the dome, embracing people from all over the world with a divine welcome of the Sun. The effect is created by 7,850 unique stars up to 43 feet wide, forming a dense geometric lattice with 1.8 per cent perforation, reminiscent of a palm tree, giving shade to tired Bedouins. Witnesses describe it as «a dizzying mirage above your head» ${ }^{1}$ (see Figure 3). Entering Louvre Abu-Dhabi, one becomes immersed in the Divine light. It is not the museum that one enters. It is the temple of culture filled with the overwhelming power of the Enlightenment.

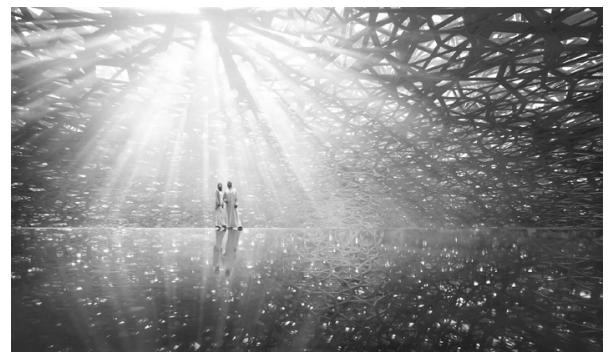

Figure 3. Inside Louvre Abu Dhabi. (C) Smithonian Magazine

The Middle-Eastern Louvre museum is, without a doubt, a unique creation of the Arab world. Of course, it is not the first Eastern museum. However, in their majority, the other ones were created in the colonial era by the Europeans and for the Europeans. In most cases, they represented collections related to the region's heritage - archaeological or ethnographic [Kuklinova, 2013]. The Louvre Abu Dhabi is a brand new concept.

This is, of course, the collection, that is the crucial point. The artworks are not from Louvre only. The collection is diverse and in-

Minutillo J. Oasis in the Desert. Architectural Record. 205 NV-2. P. 86-93. 
cludes several world masterpieces and wellknown canvases, which have become symbols of Western art long ago. All in all, there are 300 works loaned from different French museums. The museum even has its own Da Vinci portrait - La Belle Ferroniere, as if mirroring the original Louvre. The most fascinating thing from the author's point of view is the museum's acquisition of the famous recently discovered Da Vinci masterpiece - Salvator Mundi'.

Yet there is a historical déjà $v u$, the sense of the history reversed, that one experiences while observing the breathtaking splendor.

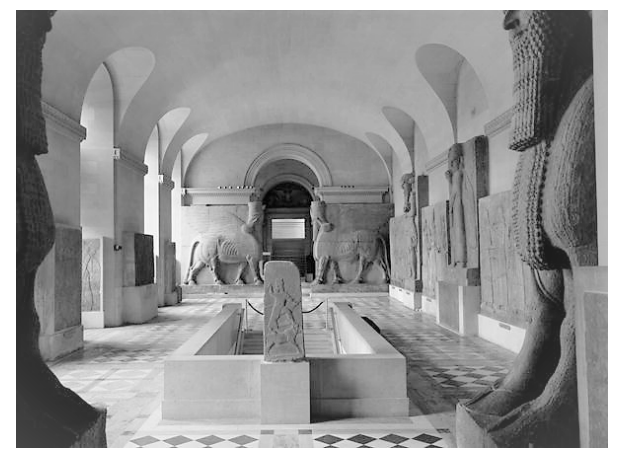

Figure 4. The Assyrian Room at the Louvre in Paris. (C) Bridgeman Images ${ }^{3}$

Louvre is one of the main cultural centres that coined the notion of Orientalism. The exploration of the self-sufficient Orient from the European point of view and in the European categories and in a patronizing way defines it [Said, 2003]. When Louvre opened its 'Assyrian Museum' comprising now more than 100000 ancient artefacts, mainly from the Middle East and Mesopotamia (see Figure 4), L'Illustration wrote then:

Nebuchadnezzar, Sardanapalus, or Ninus himself, for we don't know his actual identity, but the Assyrian monarch, in any case, sets foot on the banks of the Seine. A new, more worthly home has been destined to him, the palace of our kings. The Louvre opens wide its doors to him [Bohrer, 2003: 66].
The press promoted the image of the Louvre as a royal palace, not a museum, thus applying the traditional, historic characteristic to the contemporary identity of the place [Bohrer, 2003: 66]. While depersonalizing the Assyrian emperor, L'Illustration deprived him of his features, making him a faceless symbol of the ancient empire conquered by the modern one. At the same time English magazine run by Charles Dickens, Household Words: described Nineveh Bull in the first person quite in the same manner: "They say I am far from my violated home, in a city prouder, greater, more glorious, than my native realm» [Bohrer, 2003: $174]$. This proves that the way the country importing cultural artefacts is being viewed as glorious and triumphant is not characteristic of France only. That is the history of culture brought on foreign soil: it becomes a symbol of victory and superiority.

The process of obtaining artefacts reminds us of the eternal colonial desire to possess and master [Bohrer, 2003: 258]. The fact of Abu Dhabi generously paying for importing of European culture makes it the new City «prouder, greater, more glorious». The museum itself can be viewed as a modern temple in the desert, accumulating the symbolic power. Louvre is back in the Middle East, but now not on terms of a triumphant, on those of a subject instead. It is the first Eastern museum, condescendingly hosting European collections. It is a reflection and, at the same time, the usurper - of the name, the power, the influence. The cultural objects become strategic trophies in this case. The Renaissance Savior of the World is imprisoned in the United Arab Emirates - it is a symbolic shift of the world centre back to the Middle East, isn't it?

Jesus Christ, Leonardo, Salvator Mundi, for we can't define his actual identity, but the very qintessence of the Western civilization, sets foot on the shore of the Gulf. A new, more worthly home has been fated for him, the sanctuary of our kings. The Louvre opens wide its doors to him...

\footnotetext{
2 Abu Dhabi, the Department of Culture and Tourism, Leonardo Da Vinci's Masterpiece Salvator Mundi to Be Unveiled at Louvre Abu Dhabi on September 18. Business Wire (English). 06.28.2018.

3 Bridgeman Images: Global Masterpiece Collection. Edited by Bridgeman Images, 1st edition. 2014. Credo Reference. URL: https://search-credoreference-com.ezproxy.st-andrews.ac.uk/content/entry/bridgemanglo/the_assyrian_room_at_the_ louvre_in_paris_photo/0?institutionld=2454 (accessed 01.05.2020).
} 


\section{COMMENTARY}

Analysing the Louvre Abu-Dhabi case, I narrowed the issue in three respects.

First, the construction of giant monuments of symbolic recognition has a thousand-years tradition, so I focused on the metaphorical significance of such an ambitious project. Second, I went into the comparison of the new Louvre's acquisitions of Western art and the history of Louvre collecting Middle-Eastern artefacts, as the narratives reflect each other. I applied structuralist analysis as presented in the work of Roland Barthes 'Mythologies' to the Louvre Abu-Dhabi case. Finally, based on it, I made my conclusions on what possible symbolical impact can the creation of MiddleEastern Louvre Museum have on the world and the culture.

The Louvre Abu Dhabi case may serve as the prime example of the application of the Roland Barthes' theory to such vital sphere as soft power, including culture, politics, imagemaking on the global arena. It is indispensable in the contemporary global context, in which an image or a concept is transmitted at lightning speed. The possibility to reveal the way one sign replaces the other, distorting the signification, becomes a powerful tool, especially in the climate dominated by information wars.

Having studied the Louvre Abu Dhabi concept, I cannot fully agree with the idea of Myth as depoliticized speech [Barthes, 2014: 142]. While «the loss of historical quality of things», the process of emptying the notion of history and «filling it with [new] nature» [Barthes, 2014: 142] is self-evident in the situation, we cannot deny the idea that the myth which I had described didn't arise in a very natural way. Neither does it bear the bourgeois connotation, rather the imperial one. It is being exploited as a means of soft power and spread of the country's influence, in consequence, reshaping the world order. From this point of view, the myth proves itself to be the tool of the Right [Barthes, 2014: 149].

Still, in the analysis of the possible ideology behind the Middle-Eastern Louvre Museum, I was able to apply key Roland Barthes' ideas on mythologies in the modern world. This is particularly the case of Myth as a type of speech essay [Barthes, 2014: 109] revealing the direct connection of a myth and a discourse. The philosopher's description of the myth's structure and his tri-dimensional classification of signifiers, signifieds and signs to the signification forms the basis for my understanding of the existing problematique. The definitions of myth as a stolen language [Barthes, 2014: 109], inflexion [Barthes, 2014: 129], deformation of speech make us look into the intentions hidden behind the speech.

So, is it possible for us to conclude that Louvre Abu-Dhabi is the try to reconstruct a museum as an originally European notion? Alternatively, even the attempt to invert Orientalism by its own means?

I hold the opinion that the Middle-Eastern Louvre Museum is the perfect example of the myth, deliberately elaborated before our eyes. Roland Barthes justly notes that the myth, contrary to our belief, is usually more open than it is considered. There is nothing hidden or laid out in the myth - only the falsified and misrepresented [Barthes, 1993: 129]. Possible interpretations of the Louvre Abu-Dhabi can be those of a falsified European museum, a distorted colonial cultural centre, an unveiled global dominance manifesto.

Back in the century, the UAE were, de facto, the British territory, and Great Britain ruled the cultural institutions. In this context, it was interesting enough that by choosing Louvre as a source for the cultural import, the UAE distance themselves from the British influence. From this perspective, the choice of Louvre turns especially exciting and takes us back to the history of the Louvre collections.

It is worth noting that the public debate in France about the new museum resembled a fight. The project provoked a wave of protests. Le Monde published an open letter written by ex-director of France's Museums Francoise Cachin, ex-director of the Picasso Museum Jean Clair and an art critic Roland Recht. This letter, Museums Are Not For Sale, inspired a petition against sending French art abroad, including Abu-Dhabi. Does Louvre export French culture and art to Abu-Dhabi? Why would Louvre rent canvasses, when the regular cultural practice is to lend them? ${ }^{4}$. No- 
body could give a consistent explanation of the phenomenon.

The official Louvre position may be summarised in the words of Jean-Luc Martinez, Louvre President-Director. According to him, «it is not a European museum, it is not a European point of view, it is placed to see the world from Abu Dhabi. We [the Middle-Eastern Louvre Museum] are a bridge between Asia, Africa and Europe, important to understand the world of today» ${ }^{5}$. Still, I argued that it is more than that - the creation of the Museum has a deep symbolical meaning with the practical objectives in mind.

The light effect, which is at the base of the building's architecture is sacral in its essence. I am of the opinion that it is chosen deliberately.

We experience the light in architecture while entering the palace, cathedral. Light is traditionally associated with Divine power. In temples, it could be mirrored, disappearing in the mystical shadows, diffused, focused, or coloured up by the stained glass. In every case, it has a deep symbolical meaning, facilitating the union with God. Kurt W. Foster, Swiss historian of architecture, notes that «Light is the one element capable of transforming all others, adding something that leaves no trace once it is gone, yet one can easily overwhelm when it is present» [Light in Architecture..., 2001: 9]. Futhermore, it is the light that is the main impression of Louvre Abu Dhabi.

The use of light in the core of the Louvre Abu Dhabi building probably puts it in line with world-famous ancient temples, linking the modern trends to the archetype. Leaving apart the mainstream Christian tradition, we could draw the parallel with the Egyptian sanctuaries at Abu Simbel, Karnak, Hatshepsut's mortuary temple at Deir el-Bahri [Records in Stone, 1998: 477-493]. In Europe, we can find such striking examples as the British Stonehenge, the Greek Parthenon with the statue of the deity being illuminated by light from the three different points, Roman Pantheon, Byzantine Hagia Sophia, pierced by the Sun coming through 40 windows. We could continue the endless list of the cornerstones of the world culture and this tradition: Dome of the Rock in Jerusalem, Great Mosque in Cordoba, Japanese, Hindu Temples.

In the XVIII positivist century, when the experiments on optics deprived the light of the essence of an enigmatic emanation [Light in Architecture..., 2001: 10], it became a brilliant visual metaphor for truth and Enlightenment. Thus, Goethe praised light in «its white purity and truth» [Light in Architecture..., 2001: 14]. So, even if we distance ourselves from the possible religious interpretation, we are facing the metaphor of the temple of culture.

Thus far, we can argue that the very structure of the new museum bears the message of the new cultural Temple, open to all winds and dominating the surroundings by its presence.

Abu-Dhabi gave a powerful impulse to the new process of meaning-making. Moreover, the present-day situation with its uncertainty and fluidity of the world order provides a seedbed to coin the new brand and substitute the old imperial legend with a new one.

According to Barthes, myth is «a mode of signification, a form: type of speech, chosen by history: it cannot possibly evolve from the nature of things» [Barthes, 2014: 110]. That is exactly what we see in the Abu-Dhabi creation. Louvre here constitutes a name, a brand and a symbol, which changes its significance to the opposite one. In the nineteenth century, the Louvre was the champion, taking in the domain the timeless Assyrian culture and twisting it every way in the European imagination. "Assyria was thus Parisianized through representations like these of Courbet, Degas and Nanteuil» [Bohrer, 2014: 91]. Now it is the new, mythological 'Louvre' that exposes European culture as the opulent exotic, indistinct and incomprehensible. Barthes explains this process:

The meaning will be for the form like an instantaneous reserve of history, a tamed richness, which it is possible to call and dismiss in a sort of rapid alternation; the form must constantly be able to be rooted again in the meaning and to get there what nature it needs for its nutriment; above all, it must be able to hide there [Barthes, 2014: 118].

\footnotetext{
Abu Dhabi just opened their Louvre museum - take a look inside, online video recording, YouTube. Business Insider. 8 November 2018. URL: https://www.youtube.com/watch?v=9OMY_ADXvOo>(accessed 01.05.2020).
} 
Proceeding from the opinion that motives and intentions of the new actor (UAE) are similar to those of the previous one (French Empire), it is possible to say what happens after the new meaning is rooted [Barthes, 2014: 119]. Even though there are no significant changes in concept, the brand new story comes about, slowly but surely changing our established perception of what the world centre is in terms of politics, cultural influence and soft power. The new meaning remakes and reproduces the old one. Now Abu-Dhabi with its own Louvre becomes the City, Centre of the Empire, able to acquire all the artefacts in the world, even Salvator Mundi, the most expensive painting ever sold.

The similar sequence of causes and results with some updates is still visible here. Still, the source for the new colonialism is money and strategic alliances, not violence; the result is the increase in soft, not military, power. The conceptual basis has been reversed here, and Louvre Abu-Dhabi is no longer Parisian Louvre's «affiliated branch», but rather a usurper, robbing it of meaning and power.

Roland Barthes' semiological method of unveiling the "mythologies», innovatory for the time of publication of the eponymous book (1957), remains more than relevant up till now. Without a doubt, Roland Barthes' book «Mythologies» and its methodological content are relevant more than ever nowadays. They surely not only open the horizons for the analysts in a wide range of humanitarian fields but also can refine the worldview of any person.

\section{ЛУВР АБУ-ДАБИ ИЛИ МИФ О ВЕСТЕРНАЛИЗМЕ}

\section{Д.С. Литова}

Литова Дарья Сергеевна - магистрант образовательной программы Европейской Комиссии Erasmus Mundus по специальности «Пересечения культурных нарративов». Программа тройного диплома университетов СентЭндрюс (Шотландия), НОВА (Португалия), Перпиньяна (Франция); Университет НОВА в Лиссабоне, Факультет социально-гуманитарных наук. 1069-061, Лиссабон, Проспект Berna, 26 C. E-mail: darya.litova@gmail.com

Литова Д.С. 2020. Лувр Абу-Даби или миф о вестернализме. Конщепт: философия, религия, культура. Том 4. № 1(13). С. 194-200. https://doi.org/0.24833/2541-8831-2020-1-13-194-200

Статья поступила в редакцию: 07.11.2019. Принята к публикации: 2020.

Конфликт интересов. Автор заявляет об отсутствии конфликта интересов.

Изучение феномена Лувра Абу-Даби (Ближневосточный музей Лувра) с точки зрения истории культуры актуально в нескольких аспектах. Во-первых, представляет интерес сам факт создания этого музея как своеобразного «преемника» и «интерпретатора» западной традиции, что обуславливает его культуртрегерскую деятельность. В качестве саse-study здесь уместно обратиться к истории приобретения Лувром Абу-Даби месопотамской коллекции. Во-вторых, на данном материале можно проследить особенности развития современных стратегий конструирования идентичности с помощью «мягкой силы» и выявить, каким образом вырабатываются альтернативные культуроцентрические версии общественного развития, пересматривающие тезис о доминировании «центра» не в пользу Запада. Рассмотрение оригинального способа подачи соответствующего «западного» культурного содержания в рамках «не-западного» культурного кода позволяет поставить вопрос о вероятном рецидиве культурного империализма 
на символическим уровне. Определённые черты такого рецидива обнаруживаются в специфике организации музейного пространства и особенностях экспозиции Лувра Абу-Даби. В данной связи открывается перспектива более четко прогнозировать возможные культурные следствия создания музея и его место в направленном изменении социокультурного контекста международного взаимодействия. B-третьих, определённую теоретическую значимость имеет попытка моделирования культурных практик музея через обращение к концептам «мифологии» и «мифа», разработанных Роланом Бартом. Такое моделирование позволяет осуществить культурологическую интерпретацию деятельности музея на основе краткого изложения истории Лувра Абу-Даби сквозь призму «Мифологий» Р. Барта. В свою очередь, изучение эволюции культурного дискурса на Ближнем Востоке под влиянием инкорпорации западных культурных практик позволяет поставить вопрос о возможностях и границах использования традиционных культурных символов в качестве элементов «мягкой силы», а также обозначить ограниченный характер использования самой «мягкой силы» как средства символической власти.

Ключевые слова: постколониализм, постмодернизм, культурные цитаты, Р. Барт, мягкая сила, Лувр, музейные исследования, архитектура, свет, мифология.

\section{References:}

Light in Architecture and Art. 2001. The Work of Dan Flavin. A Symposium Hosted by the Chinati Foundation, Marfa, Texas, May 5 and 6, 2001; with Lectures by Tiffany Bell, Kurt W. Forster, Michael Govan, Dave Hickey, Steve Morse, Robert Rosenblum, Brydon Smit'. Marfa, Texas : Chinati Foundation. 183 p.

Barthes R. 1993. Mythologies. Trans. Annette Lavers. London: Vintage. 158 p.

Barthes R. 2014. Mythologies. Paris: Éditions du Seuil. (Imprint 1957). 272 p.

Baudrillard J. 2003. The Spirit of Terrorism and Other Essays. Trans. Chris Turner. London: Verso. 105 p.

Bohrer F.N. 2003. Orientalism and Visual Culture: Imagining Mesopotamia in Nineteenth CenturyEurope. New York: Cambridge University Press. 398 p.

Culler J. 2002. Barthes: A Very Short Introduction. Oxford: OUP. 160 p.

Kuklinova I.A. 2013. Louvre of Abu Dhabi: A Universal Museum in the Arabic World. Problems of Museology. № 1. P. 156-162.

Records in Stone : Papers in Memory of Alexander Thom. 1988. Edited by C.L.N. Ruggles. Cambridge : Cambridge University Press. 540 p.

Said E.W. 2003. Orientalism. London : Penguin books. 396 p. 